\title{
Gross Morphological and Histomorphometric Observations of Udder in Boer Local She-Goats
}

\author{
S. Senthilkumar ${ }^{1 *}$, T. A. Kannan ${ }^{1}$, R. Gnanadevi ${ }^{1}$, Geetha Ramesh ${ }^{1}$ and D. Sumathi ${ }^{2}$ \\ ${ }^{1}$ Department of Veterinary Anatomy, ${ }^{2}$ Department of Veterinary Clinical Medicine, Madras \\ Veterinary College, Chennai-600 007, India \\ *Corresponding author
}

\section{A B S T R A C T}

Keywords

Mammary gland, Boer local she-goat, Gross morphology, Histology

\section{Article Info}

Accepted:

15 December 2019

Available Online:

20 January 2020
The objective of this study was to explore the gross morphological and histolmorphometric observations in the mammary gland of Boer graded local goats in India. The present study was conducted in adult lactating and nonlactating ( $\mathrm{n}=6$ each) Boer local she-goats. The mammary gland in both the group was a compound tubulo-alveolar gland surrounded by a connective tissue capsule. The alveoli were the principal secretory unit lined by simple cuboidal epithelium. In lactating animals, well developed alveoli, filled with secretions and lipid droplets were observed. The non-lactating alveoli was dry, shrunken contained obliterated lumen without lipid droplets. The connective tissue stroma was well developed in non-lactating animals. Alveolar and intralobular ducts were lined by simple cuboidal epithelium. Interlobular and large lactiferous ducts were lined by bilayered cuboidal epithelium. Significant difference was observed in the length of lobule, breadth of lobule, number of alveoli per lobule, alveoli size, alveolar luminal diameter, nucleus diameter and epithelial thickness of alveoli.

\section{Introduction}

Small ruminants play an important role in the food and nutritional security of millions of rural people especially the landless, marginal and small farmers in arid and semiarid rainfed regions. The socio-economic value of small ruminant rearing as compared to other livestock species, for poor farmers is immense
(Kumar and Roy et al., 2013). Boer local is a crossbreed goat evolved by crossing Boer and Local goats at Post Graduate Research Institute in Animal Sciences unit of Tamil Nadu Veterinary and Animal Sciences University. Gross anatomical and histomorphometric studies on the udder of various breeds were determined by several authors. But to our best knowledge, no such 
work was reported in Boer graded local goats reared in Post Graduate Research Institute in Animal Sciences unit of Kattupakkam.

Hence, the present study was conducted with the aim of establishing basic data about gross morphological and histomorphometry of mammary gland in lactating and non-lactating and Boer local she-goat.

\section{Materials and Methods}

The udder samples of Boer local she-goats were collected immediately after slaughter of animals from local slaughter houses, kattupakkam. Age of the animals was determined by dentition. After collection, samples were directly fixed in 10 per cent neutral buffered formalin, Zenker's fluid, and Bouin's fluid.

Collected tissues were processed by routine Alcohol-xylene schedule and paraffin blocks were made (Luna, 1968). Sections were cut at 5-7 $\mu \mathrm{m}$ thickness for histological study. Haematoxylin and Eosin (H\&E) method for the routine histological study and Masson's trichrome staining for collagen fibres. Microscopic images were captured using the Leica microscope (CH9345 Heerbrugg). Micrometry was done using the Leica application suite (LAS V4.4) as reported by Senthilkumaret al., (2019).

The micrometrical parameters such as capsule thickness, length of lobule, breadth of lobule, number of alveoli per lobule, alveolar size, alveolar luminal diameter, number of cells per alveoli, height of alveolar epithelium, epithelial height of interlobular duct, epithelial height of intralobular duct, nucleus diameter, internuclear distance were measured in mammary glands of both lactating and nonlactating groups of Boer local she-goats. Collected data were subjected to statistical analysis by $\operatorname{SPSS}^{\circledR} 26.0$ for Windows.

\section{Results and Discussion}

\section{Gross morphology}

In the present study, the udder was located in the inguinal region in both the groups of shegoat. It consisted of two mammary glands (right and left halves) and each had a single teatas reported by Turner (1952), Small wood (1993) in small ruminants. Externally, the mammary groove indicated the division of udder into two mammary glands(Fig 1). Each half was located on either side of the midventral line and was found to be symmetrical. Each gland was covered by the skin which was continuous with the skin covering the mid-ventral aspect of the inguinal region. In she-goats, the udder skin was pigmented, the hairs were found to be thinner and less dense throughout the gland. Fine hairs were also found covering the teat in she-goat. In the present study, each mammary gland was continuous with a single teat. Each teat consisted of three parts such as base, body and apex / tip of the teatas per Dyce et al., (2010) in small ruminants.

\section{Histomorphometry}

In lactating and non-lactating Boer local shegoats histological composition of parenchyma was found to be similar. However, the difference in proportion was observed between lactating and non-lactating animals. Parenchyma was made up of numerous lobes and lobules consisted of tubulo-alveolar secretory units surrounded by connective tissue septa (Fig 2). Various micrometric parameters of the mammary gland of Boer local she-goats were given in Table 1. The proportion of interlobular septa and adipose tissue were found to be more in non-lactating group than lactating group. The blood vessels were also found to be more in lactating parenchyma compared to non-lactating parenchyma. These observations are in 
concurrence with the findings of Chaurasiaet al., (2016) in buffaloes.

Alveoli varied from round to oval in shape and lined by simple cuboidal epithelium with intracytoplasmic vacuolation. Nucleus was round and intensely basophilic in lactating alveolus when compared to non-lactating alveolus. The lumen of the alveoli was filled with eosinophilic material (Fig 4). In lactating animals, fat droplets of varied sizes were observed within the alveolar cells and in the lumen of the alveoli in both the species.

However, the average lipid droplet diameter was found to be more in lactating she-goats. A similar observation was made by Park et al., (2007). Whereas, in non-lactating animals, alveoli were reduced in size with empty lumen causes less luminal diameter. In non-lactating animals, the alveoli were fully devoid of secretions and it became dry and shrunken (Fig 3).In the present study, both lactating and non-lactating groups showed the presence of myoepithelial cells between the lining epithelium and basement membrane of the alveoli (Fig 4). They were also observed in the duct system. These cells were angular or flat or spindle-shaped with the elongated or oval vesicular nucleus. The long axis of these cells was parallel to the basement membrane. Myoepithelial cell length and breadth was observed as $10.17 \pm 0.85,1.53 \pm 0.16$ and $10.23 \pm 0.60,1.19 \pm 0.27$ respectively in lactating and non-lactating she goats.

In Boer local she-goats, length and breadth of lobule were found to be $1063.80 \pm 67.5$ and $855.45 \pm 77.5$ respectively in the lactating group and $669.23 \pm 64.0$ and $494.5 \pm 98.0$ in the non-lactating group. The number of alveoli per lobule were $34.87 \pm 2.77$ and $19.58 \pm 2.82$ in lactating and non-lactating she-goats respectively. Highly significant difference was observed in length and breadth of the lobule between lactating and non-lactating group. This indicates the secretory activity of the alveoli during lactation.

Similarly, in lactating she-goats, the alveolar size $(\mu \mathrm{m})$, the diameter of alveolar lumen $(\mu \mathrm{m})$ and a number of lining epithelial cells per alveoli were $71.26 \pm 3.86,57.85 \pm 3.45$ and $19.08 \pm 1.35$ respectively, whereas, it was $52.48 \pm 2.38,29.60 \pm 2.64$ and $24.25 \pm 3.56$ respectively in non-lactating she-goats. The number of alveoli per lobule was significantly differed between lactating and non-lactating group. These findings were supported by Paramasivan et al., (2013) in ewes. This can be attributed to the fact that lobule size was more in lactating animals comprising more alveoli. Whereas, in non-lactating animals, small sixed lobules had less number of degenerated and shrunken alveoli.

Similarly, in lactating she-goats, the height of alveolar epithelium $(\mu \mathrm{m})$, the diameter of its nucleus $(\mu \mathrm{m})$ and internuclear distance $(\mu \mathrm{m})$ were found to be $13.38 \pm 0.72,5.66 \pm 0.22$ and $4.22 \pm 0.46$ respectively and $11.19 \pm 0.72$, $3.07 \pm 0.15$ and $4.01 \pm 0.72$ respectively in non-lactating she-goats. Alveolar epithelial height differed significantly between lactating and non-lactating groups of she-goats. Dyce $e t$ al., (2002) informed that the alveolar epithelial height had increased in lactating ruminants. Similar, findings was seen in the present study also.

In this study, a highly significant difference was observed in the nucleus diameter between lactating and non-lactating groups. A similar finding was made by Paramasivan (2007) in ewes. The lesser values in nucleus diameter in lactating animals might be due to higher synthetic activity of alveolar epithelial cells during lactation. 
Table.1 Mean \pm SE of various micrometric parameters in the mammary gland of Boer local shegoats

\begin{tabular}{|c|c|c|c|}
\hline \multirow{2}{*}{ Parameters $(\boldsymbol{\mu m})$} & \multicolumn{2}{|c|}{ Mean \pm SE } & \multirow{2}{*}{ t value } \\
\cline { 2 - 3 } & $\begin{array}{c}\text { Lactating } \\
(\mathbf{N = 6})\end{array}$ & $\begin{array}{c}\text { Non-lactating } \\
(\mathbf{N}=\mathbf{6})\end{array}$ & \\
\hline Length of lobule & $1063.80 \pm 67.5$ & $669.23 \pm 64.0$ & $4.95^{* *}$ \\
\hline Breadth of lobule & $855.45 \pm 77.5$ & $494.5 \pm 98.0$ & $2.29^{* *}$ \\
\hline Number of alveoli per lobule & $34.87 \pm 2.77$ & $19.58 \pm 2.82$ & $3.68^{* *}$ \\
\hline Alveolar size & $71.26 \pm 3.86$ & $52.48 \pm 2.38$ & $3.64^{* *}$ \\
\hline Alveolar luminal diameter & $57.85 \pm 3.45$ & $29.60 \pm 2.64$ & $5.91^{* *}$ \\
\hline Number of cells per alveoli & $19.08 \pm 1.35$ & $24.25 \pm 3.56$ & $1.55^{\mathrm{NS}}$ \\
\hline Epithelial height of alveoli & $13.38 \pm 0.72$ & $11.19 \pm 0.72$ & $2.05^{*}$ \\
\hline Nucleus diameter & $3.07 \pm 0.15$ & $5.66 \pm 0.22$ & $8.63^{* *}$ \\
\hline Internuclear distance & $4.22 \pm 0.46$ & $4.01 \pm 0.72$ & $0.26^{\mathrm{NS}}$ \\
\hline Myoepithelial cell length & $10.17 \pm 0.85$ & $10.23 \pm 0.60$ & $0.05^{\mathrm{NS}}$ \\
\hline Myoepithelial cell breadth & $1.53 \pm 0.16$ & $1.19 \pm 0.27$ & $0.49^{\mathrm{NS}}$ \\
\hline Epithelial height of the intralobular duct & $17.43 \pm 2.30$ & $12.52 \pm 1.10$ & $1.91^{\mathrm{NS}}$ \\
\hline Epithelial height of the interlobular duct & $16.65 \pm 2.21$ & $15.61 \pm 1.64$ & $0.37^{\mathrm{NS}}$ \\
\hline
\end{tabular}

NS - No significant difference between lactating and non-lactating groups $(\mathrm{P} \geq 0.05)$

* - Significant difference between lactating and non-lactating groups $(\mathrm{P} \leq 0.05)$

* - Highly significant difference between lactating and non-lactating groups $(\mathrm{P} \leq 0.01)$

Fig.1 Photograph of the udder of adult Boer local she-goat

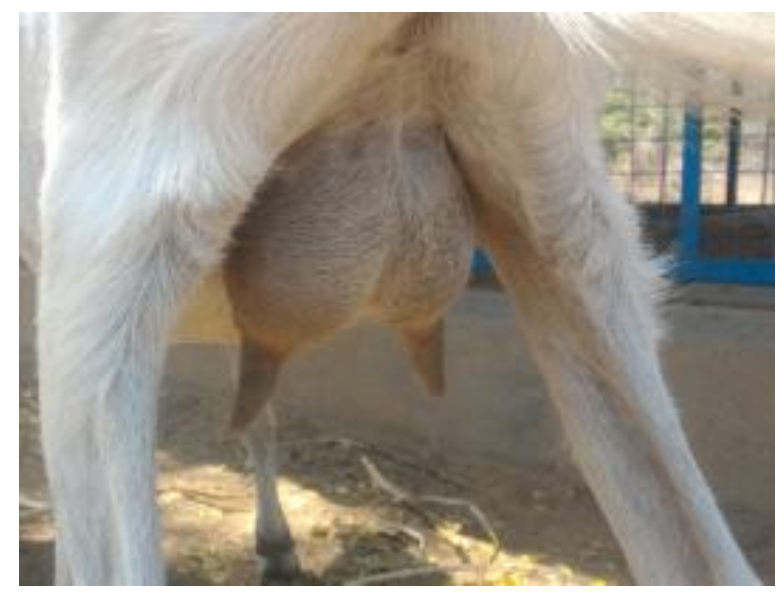


Fig.2 Photomicrograph of the mammary gland of an adult lactating Boer local she-goat

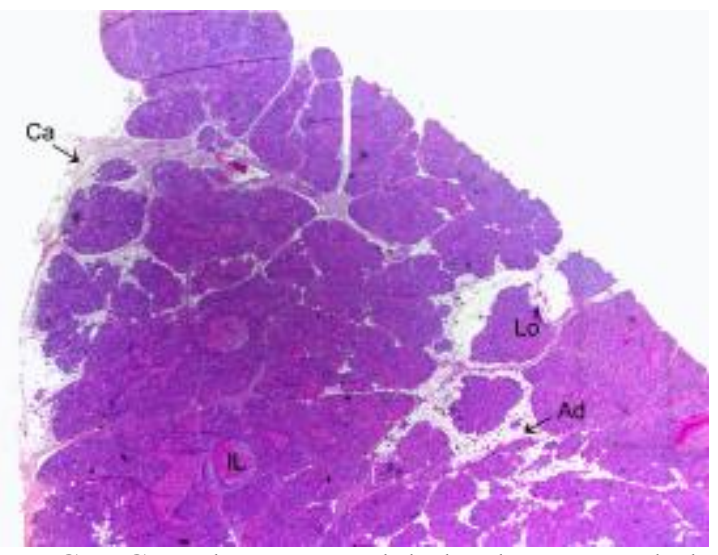

Ad - Adipose tissue Ca - Capsule IL - Interlobular duct Lo -Lobule

$\mathrm{H} \& \mathrm{E} \times 12.5$

Fig.3 Photomicrograph of the mammary gland of an adult non-lactating Boer local she-goat

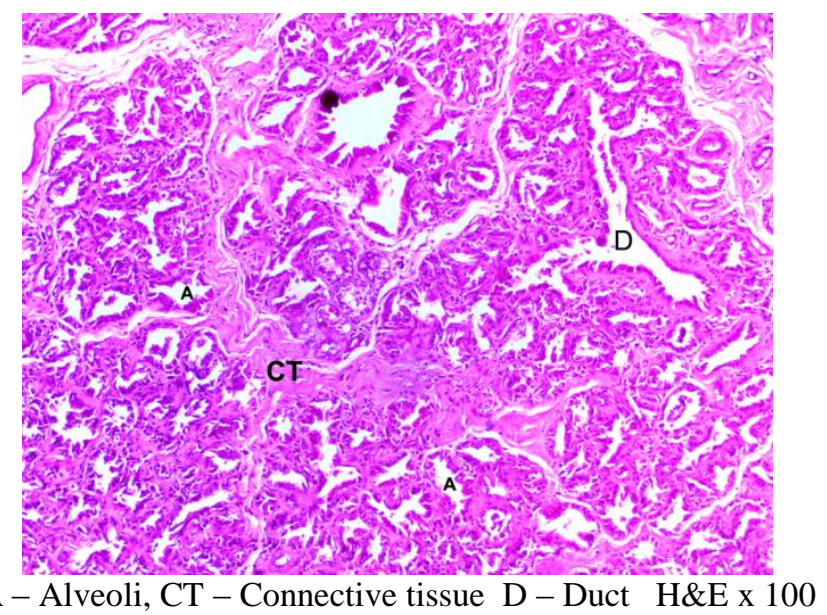

Fig.4 Photomicrograph of the mammary gland of an adult lactating Boer local she-goatshowing Alveoli (A), Connective tissue (CT), Secretions (S) lipid droplets (Arrow heads) and myoepithelial cells (arrow)

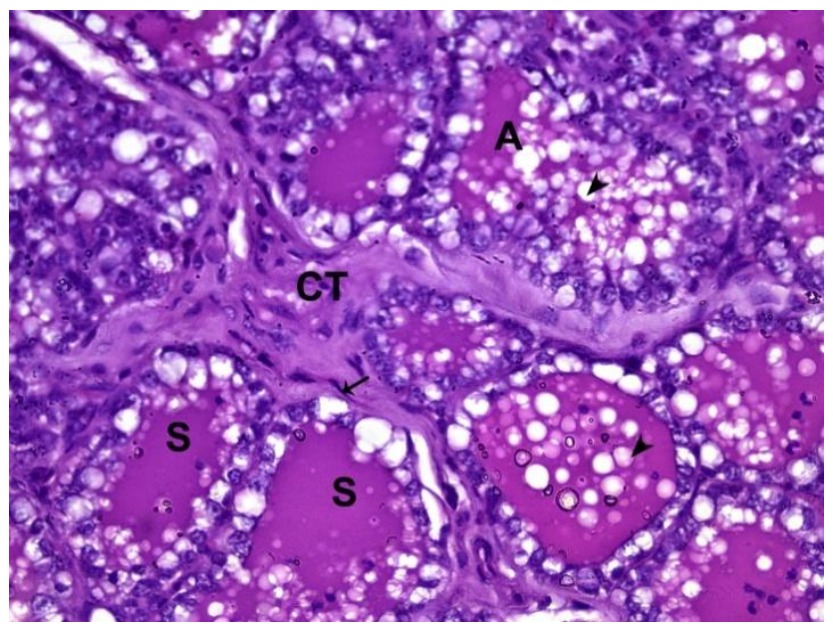

$\mathrm{H} \& \mathrm{E} \times 400$ 
Fig.5 Photomicrograph of the mammary gland of an adult lactating Boer local she-goat showing Alveoli (A), Connective tissue (CT), Secretions (S) lipid droplets (Arrow heads) and myoepithelial cells (arrow)

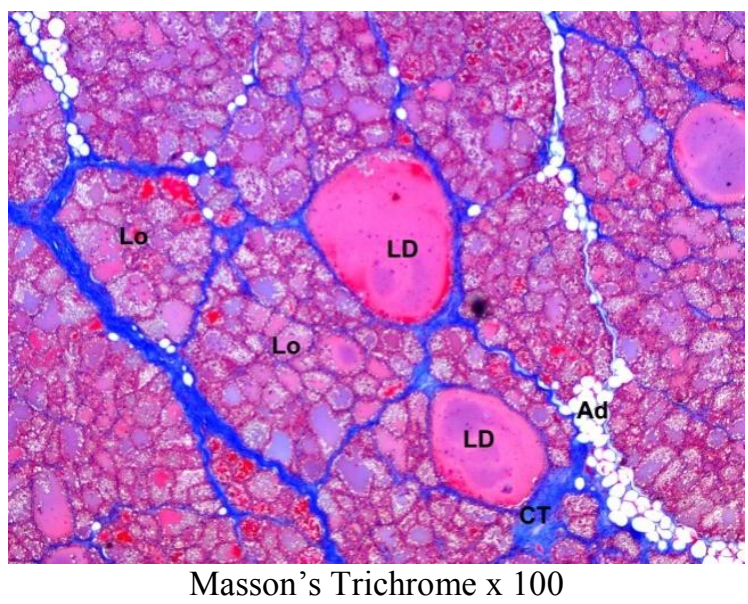

Whereas, no significant difference was observed in internuclear distance between lactating and non-lactating groups of Boer local she-goats. This is in accordance with the findings made by Paramasivanet al., (2016) in ewes.

In the present study, both lactating and nonlactating animals, the duct system was composed of several ducts in the following order viz., alveolar duct, intralobular duct, interlobular duct, intralobar duct, interlobar duct, and lactiferous duct (Fig 5) which conveyed the milk from the alveoli into the gland cistern.

Alveolar and intralobular ducts were lined by simple cuboidal epithelium rested upon the basement membrane. Interlobular, intralobar and interlobar ducts were lined by two layers of cuboidal cells. Small dilatations were observed along the course of the ductular system. The amount of connective tissue component increased as the order of duct increases. Longitudinal smooth muscle fibres were also observed within the wall of these ducts. This is in total agreement with the observations made by Dellman and Brown (1987) in ruminants.
Ducts showed the presence of dilatations within their walls whose lumen was filled with eosinophilic material was observed in the present study as per Frandsonet al., (2009) in mammary gland of cow.

The epithelial height of intralobular and interlobular ducts $(\mu \mathrm{m})$ was found to be 17.43 $\pm 2.30,16.65 \pm 2.21$ and $12.52 \pm 1.10,15.61 \pm$ 1.64 respectively in lactating and non-lactating she-goats. In this study, no significant difference was observed in epithelial height of intralobular and interlobular ducts between lactating and non-lactating ewes and shegoats. This is in contrast to the findings of Paramasivan (2007) in ewes.

\section{Acknowledgement}

The author acknowledges the Dean, Madras Veterinary College and the authorities of Tamil Nadu Veterinary and Animal Sciences University, Chennai for providing necessary facilities to carry out the research work.

\section{References}

Kumar, S and M.M. Roy, 2013.Small Ruminant's Role in Sustaining Rural 
Livelihoods in Arid and Semiarid Regions and their Potential for Commercialization New Paradigms in livestock production from traditional to commercial farming and beyond (Eds).Agrotech publishing academy, Udaipur, pp. 57-80

Bancroft, J.D. and M. Gamble, 2003.Theory and Practice of Histological Techniques. 5th Edn., Churchill and Livingstone, New York, 593-620

Chaurasia, D., R.S. Dalvi, S.B. Banubakode, N.C. Nandeshwar, R. Churchan, S.P. Ingole and B. Sinha, 2016. Histological study on stromal tissue in mammary gland at lactating, involution and pregnant stage in murrah buffalo.Buffalo Bulletin, 35(1): 49-57.

Dellman.H, and M. Brown, 1987. Textbook of veterinary histology, 3rd edition., Lea and febiger, Philadelphia, 340-341.

Dyce, K.M., W.O. Sack and C.J.G Wensing, 2002.Textbook of Veterinary Anatomy. 3rd edition., Saunders Elsevier, USA, 723-731.

Dyce, K.M., W.O. Sack and C.J.G. Wensing, 2010.Textbook of Veterinary Anatomy. 4th edition., Elsevier health, St.louis, 727.

Frandson, D.R., W.L. Wilke and A.D. Fails, 2009. Anatomy and physiology of farm animals. 7th Edn., 449-456.

Paramasivan, S., 2007. Gross anatomical and histomorphological studies on hypothalamo-hypophysio-mammary axis of sheep (Ovisaries). (Ph.D thesis), TANUVAS - Chennai, India.

Paramasivan, S., Geetha Ramesh, S. Ushakumary, S. Venkatesan, K. Kulasekar and C. Balachandran, 2016. Histophysiological studies on the hypophysio - Mammary axis in sheep (Ovisaries) - mammotrophs. International Journal of Science, Environment and Technology, 5(3): $912-917$.

Paramasivan, S., Geetha Ramesh, S. Ushakumary, S.H. Basha, T.A. Kannan and A. Kumaravel, 2013.Gross and microscopic anatomy of teat in Madras Red sheep.Indian Veterinary Journal, 90(4): 44-47.

Park, Y.W., M. Juarez, M. Ramos, G.F.W. Haenlein, 2007. Physico-chemical characteristics of goat and sheep milk.Small Ruminant Research, 68: $88-113$.

Smallwood, J.G., 1993. A Guided Tour of Veterinary Anatomy. W.B. Saunders Company. 109-112

Senthilkumar, S., T.A. Kannan, Geetha Ramesh and Sumathi, D. 2019.Histological and Immunohistochemical Observations of Supramammary Lymph Node in Sheep and Goat.Int.J.Curr.Microbiol.App.Sci. 8(08): 74-82.

Turner, C.W., 1952. The mammary gland The Anatomy of the udder of cattle and domestic animals.Lucas brothers Publishers, Columbia, 35.

\section{How to cite this article:}

Senthilkumar, S., T. A. Kannan, R. Gnanadevi, Geetha Ramesh and Sumathi, D. 2020. Gross Morphological and Histomorphometric Observations of Udder in Boer Local She-Goats. Int.J.Curr.Microbiol.App.Sci. 9(01): 445-451 doi: https://doi.org/10.20546/ijcmas.2020.901.048 